\title{
Types of Swine Diets ${ }^{1}$
}

\section{Joel Brendemuhl and Bob Myer ${ }^{2}$}

\section{INTRODUCTION}

Various classes of swine have particular nutrient requirements. In general, young pigs require greater dietary levels of most nutrients such as protein (lysine) than older pigs. As such, there are various diets on the market, or that can be mixed on the farm, that are suited for each class of swine.

These diet types usually include the following:

- Starter (or Nursery)

- Grower-Finisher

- Gestation

- Lactation

- Farrowing

- Gilt Developer

- Boar

Lysine content is important because swine, like most non-ruminant animals, require specific levels of amino acids that make up protein instead of protein per se. Some of these amino acids are essential and must be present in the diet for pigs to grow and perform well. A few essential amino acids tend to be limiting in typical swine diets. One essential amino acid, lysine, is usually the most limiting, or first limiting. This means that if a diet is formulated to supply the correct amount of lysine, then generally the levels of other essential amino acids (protein) will be adequate. Therefore, lysine is an important consideration when choosing the proper swine diet. After lysine, other limiting amino acids in typical swine diets include threonine, methionine and tryptophan.

\section{STARTER DIETS}

Starter diets are designed to be the first dry feeds that a newly weaned pig consumes. The diets normally contain dried milk products (lactose, whey, deproteinized whey, skim milk), animal protein products (fish meal, dried blood, dried plasma), a fat source (choice white grease), an antibiotic, a diet acidifier, vitamin and mineral premixes, corn and soybean meal. Most farms use a phase-feeding program during the nursery (weaning until pigs weigh 50 pounds) and the number of phases (diets) used depends upon the age and weight of the pigs weaned. For early weaned pigs ( $<21$ days of age; weighing 8 to 12 pounds), an early-weaning diet is recommended that would contain $1.65 \%$ total lysine ${ }^{2}$ (about $23 \%$ crude protein). This type of diet would be fed for a limited time, and only 2 to 3 pounds of this diet per pig is recommended. Following this, a Starter- 1 diet is fed ( $1.50 \%$ total lysine; about $21 \%$ crude protein) until pigs weigh approximately 15 pounds. The Starter-1 diet normally contains less animal protein product and no deproteinized whey. Normal consumption of the

1. This document is AS44, one of a series of the Animal Sciences Department, Florida Cooperative Extension Service, Institute of Food and Agricultural Sciences, University of Florida. Original publication date April 1989. Revised September 2009. Reviewed August 2012. Visit the EDIS website at http:// edis.ifas.ufl.edu.

2. Joel Brendemuhl, professor, Department of Animal Sciences; Bob Myer, professor, Department of Animal Sciences; North Florida Research and Education Center (REC)--Marianna FL; Florida Cooperative Extension Service, Institute of Food and Agricultural Sciences, University of Florida, Gainesville, FL 32611. 
Starter- 1 diet is 5 to 6 pounds per pig. A Starter-2 nursery diet (1.35\% total lysine; about $21 \%$ crude protein) follows the Starter-1 diet until pigs weigh approximately 25 pounds. The final starter diet is Starter-3 which contains $1.25 \%$ total lysine (about $20 \%$ crude protein), and this is fed until pigs weigh approximately 50 pounds and are now 7 to 8 weeks of age. The early-weaning diet can also be fed as a creep diet for young pigs still nursing the sow. For pigs weaned at 3 to 4 weeks of age, the early-weaning diet could be skipped, and pigs could begin with the Starter- 1 diet. For pigs weaned at 5 to 6 weeks of age, pigs could begin immediately after weaning on the Starter-2 diet. Example starter diets are presented in Table 1. Because of the complex ingredients used in the starter diets, it is recommended that commercially prepared complete diets are purchased especially for the early-weaning and Starter-1 diets. Although buying prepared commercially available Starter- 2 and -3 diets is recommended, these diets can be mixed at the farm with the purchase of commercial base mixes or supplements.

\section{GROWER-FINISHER DIETS}

Grower-Finisher diets are fed to pigs from 50 pounds to market weight (approximately 270 pounds). These diets are also phase fed and typically there are four phases. The first phase from 50 to 100 pounds is a diet that is self-fed, and contains approximately $1.15 \%$ total lysine (18 to $19 \%$ crude protein). The remaining phases are also all self-fed diets where the lysine (protein) concentration is reduced with each new phase. In addition to reducing lysine content, the latter phases would also require less total protein, vitamins and minerals which help to reduce diet cost. The remaining phases would typically be as follows: 100 to 150 pounds (0.95\% total lysine; about $16 \%$ crude protein); 150 to 200 pounds ( $0.85 \%$ total lysine; about $15 \%$ crude protein) and 200 to market weight ( $0.70 \%$ total lysine; 13 to $14 \%$ crude protein). Grower-Finisher diets are normally corn and soybean meal based with added vitamins, minerals, a fat source, and other potential feed additives. These diets are usually mixed on the farm but can be purchased commercially from feed companies. Example grower-finisher diets are presented in Table 2.

\section{GESTATION DIETS}

This diet type, as the name implies, is fed to gestating sows. This diet can also be fed to breeding age boars. Gestation diets are typically formulated to contain $0.60 \%$ total lysine (12 to 13\% crude protein). Gestation diets are limit fed (3.5 to 5 pounds per head per day) to avoid obesity in the breeding herd. They normally contain higher levels of vitamins and minerals than swine grower-finisher diets in order to meet daily requirements under a limit feeding program. An example sow gestation diet is presented in Table 3.

\section{LACTATION DIETS}

This type of diet is fed to lactating sows. Lactation diets contain $1.0 \%$ total lysine (18 to $19 \%$ crude protein) and higher levels of vitamins and minerals than finisher diets due to higher nutrient requirements to support lactation. These diets are normally fed stair-wise (increasing amounts each day) until full-fed at around 7 to 8 days of lactation. In the past, producers have fed the gestation diet to lactating sows to simplify their feeding program, but this should not be done as the gestation diet is not adequate to support the nutrient needs of the lactating sow. An example lactation diet is given in Table 3.

\section{FARROWING DIETS}

This optional diet type is designed to be fed to sows a few days before farrowing and continued for a few days after farrowing. These diets are designed to minimize potential problems with constipation or other problems that may occur at farrowing time. Farrowing diets are generally mixed by adding bulk (i.e., fibrous feeds like wheat bran, beet pulp, or alfalfa meal) or mineral laxatives to normal lactation diets. A separate farrowing diet is optional and is only necessary if constipation or other farrowing problems are present within your herd. An example diet is presented in Table 3.

\section{GILT DEVELOPER DIETS}

Some commercial supplement programs and feed companies may recommend this diet type. Diets of this type are fed to replacement gilts weighing 200 pounds until they are bred. These diets are similar to gestation diets and gestation diets will work for those producers who don't want to bother with a separate gilt developer diet. If the gestation diet is used it should be fed at a level to support growth of the gilt but limit the amount of fat that she deposits.

\section{BOAR DIETS}

Boars that are used either for a natural or artificial mating program can be fed a grain-soybean meal diet similar to a gestation diet. The diet should be limit-fed but feed level should be changed to reflect differences in season, condition and workload of the boar. Normal feeding amounts are 4 to 5 pounds per head per day but boars worked heavily or in thinner condition should be fed 6 to 7 pounds per head per day. 


\section{SUMMARY}

Several types of swine diets are available to swine producers for various classes of swine. Different diets are necessary in order to meet the varying requirements of each class. In order to simplify the feeding system on swine farms, the number of diets necessary can be minimized by combining certain classes and feeding one diet to each. Examples would be feeding just one starter diet instead of 3 or 4 , feeding one breeding diet instead of a separate gestation and lactation diet, and feeding just one grower and one finisher diet instead of multiple grower and finisher diets. However, if one chooses to minimize their diets by combining certain classes this will reduce performance and may also increase feed costs resulting in an overall increase in production costs.
A related EDIS publication, AN083: Understanding Swine Feeding Programs, can be found at http://edis.ifas.ufl.edu/ AN083.

Table 1. Example Compositions of Swine Starter Diets

\begin{tabular}{|c|c|c|c|c|}
\hline \multirow[t]{2}{*}{ Ingredients and Composition } & $\begin{array}{l}\text { Early-Wean } \\
\text { Pigs 8-12 lbs }\end{array}$ & $\begin{array}{l}\text { Starter }-1 \\
\text { Pigs } 12-15 \mathrm{lbs}\end{array}$ & $\begin{array}{l}\text { Starter }-2 \\
\text { Pigs } 15-25 \mathrm{lbs}\end{array}$ & $\begin{array}{l}\text { Starter }-3 \\
\text { Pigs } 25-50 \mathrm{lbs}\end{array}$ \\
\hline & \multicolumn{4}{|c|}{ Pounds of Ingredients } \\
\hline Ground Corn & 805 & 818 & 1108 & 1286 \\
\hline Soybean Meal & 300 & 360 & 480 & 550 \\
\hline Porcine Plasma Meal & 110 & 55 & 0 & 0 \\
\hline Menhaden Fish Meal & 120 & 100 & 100 & 40 \\
\hline Spray-Dried Blood Meal & 20 & 20 & 0 & 0 \\
\hline Dried Whey & 500 & 500 & 200 & 0 \\
\hline Choice White Grease & 100 & 100 & 60 & 60 \\
\hline Monocalcium Phosphate, 21\% P & 12 & 12 & 15 & 21 \\
\hline Ground Limestone & 10 & 11 & 12 & 18 \\
\hline Salt & 5 & 5 & 6 & 6 \\
\hline Vit-TM Premix ${ }^{a}$ & 4 & 4 & 4 & 4 \\
\hline L-Lysine $\mathrm{HCl}$ & 3 & 3 & 4 & 4 \\
\hline DL-Methionine & 1 & 2 & 1 & 1 \\
\hline L-Threonine & 0 & 0 & 0 & 0 \\
\hline Antibiotic Premix & 10 & 10 & 10 & 10 \\
\hline TOTAL & 2,000 & 2,000 & 2,000 & 2,000 \\
\hline \multicolumn{5}{|l|}{ Composition: } \\
\hline Protein, $\%$ & 22.6 & 21.2 & 20.4 & 19.7 \\
\hline Lysine,\% & 1.64 & 1.50 & 1.35 & 1.25 \\
\hline Calcium, $\%$ & 0.88 & 0.85 & 0.80 & 0.75 \\
\hline Phosphorus,\% & 0.80 & 0.75 & 0.70 & 0.65 \\
\hline
\end{tabular}


Table 2. Example Compositions of Swine Grower-Finisher Diets

\begin{tabular}{|c|c|c|c|c|}
\hline \multirow[t]{2}{*}{ Ingredients and Composition } & $\begin{array}{l}\text { Grower }-1 \\
\text { Pigs } 50-100 \text { lbs }\end{array}$ & $\begin{array}{l}\text { Grower }-2 \\
\text { Pigs } 100-150 \text { lbs }\end{array}$ & $\begin{array}{l}\text { Finisher }-1 \\
\text { Pigs } 150-200 \mathrm{lbs}\end{array}$ & $\begin{array}{l}\text { Finisher }-2 \\
\text { Pigs } 200 \text { lbs to } \\
\text { market weight }\end{array}$ \\
\hline & \multicolumn{4}{|c|}{ Pounds of Ingredients } \\
\hline Ground Corn & 1343 & 1464 & 1565 & 1650 \\
\hline Soybean Meal & 540 & 424 & 350 & 270 \\
\hline Choice White Grease & 60 & 60 & 40 & 40 \\
\hline Monocalcium Phosphate, 21\% P & 22 & 19 & 15 & 12 \\
\hline Ground Limestone & 20 & 20 & 17 & 16 \\
\hline Salt & 6 & 6 & 6 & 6 \\
\hline Vit-TM Premix & 4 & 4 & 4 & 4 \\
\hline L-Lysine HCl & 4 & 3 & 3 & 2 \\
\hline DL-Methionine & 1 & 0 & 0 & 0 \\
\hline TOTAL & 2,000 & 2,000 & 2,000 & 2,000 \\
\hline \multicolumn{5}{|l|}{ Composition: } \\
\hline Protein, $\%$ & 18.5 & 16.2 & 14.9 & 13.4 \\
\hline Lysine, $\%$ & 1.15 & 0.95 & 0.85 & 0.70 \\
\hline Calcium,\% & 0.70 & 0.65 & 0.55 & 0.50 \\
\hline Phosphorus,\% & 0.60 & 0.55 & 0.50 & 0.45 \\
\hline
\end{tabular}


Table 3. Example Sow Diets

\begin{tabular}{|c|c|c|c|}
\hline Ingredients and Composition & Gestation & Lactation & Farrowing \\
\hline Ground Corn & 1642 & 1325 & 1077 \\
\hline Soybean Meal & 250 & 550 & 500 \\
\hline Choice White Grease & 40 & 60 & 60 \\
\hline Monocalcium Phosphate, 21\% P & 27 & 26 & 20 \\
\hline Ground Limestone & 23 & 21 & 25 \\
\hline Salt & 10 & 10 & 10 \\
\hline Vit-TM Premix ${ }^{a}$ & 4 & 4 & 4 \\
\hline Wheat Bran & 0 & 0 & 300 \\
\hline Chromax ${ }^{b}$ Premix & 1 & 1 & 1 \\
\hline Choline Chloride - $60 \%{ }^{c}$ & 3 & 3 & 3 \\
\hline L-Lysine $\mathrm{HCl}$ & 0 & 0 & 0 \\
\hline DL-Methionine & 0 & 0 & 0 \\
\hline TOTAL & 2,000 & 2,000 & 2,000 \\
\hline Protein, $\%$ & 12.8 & 18.4 & 18.6 \\
\hline Lysine,\% & 0.60 & 1.00 & 1.00 \\
\hline Calcium,\% & 0.75 & 0.75 & 0.80 \\
\hline Phosphorus,\% & 0.60 & 0.65 & 0.70 \\
\hline \multicolumn{4}{|c|}{$\begin{array}{l}\text { aThis is a commercially available vitamin-trace mineral premix intended to be used at } 4 \text { pounds per ton of feed. Please refer to your } \\
\text { manufacturer's directions when including the vitamin and trace mineral premixes you may purchase. } \\
\text { bSupplies } 200 \mathrm{ppb} \text { chromium as chromium picolinate and was added at the expense of } 0.05 \% \text { limestone. } \\
\text { 'Supplies } 780 \mathrm{ppm} \text { choline in the final diet. }\end{array}$} \\
\hline
\end{tabular}

